\title{
東北地方太平洋沖地震による地震動の特徵 Strong-motion characteristics during the 2011 Tohoku earthquake
}

\author{
大野 晋 ${ }^{a) *}$ \\ Susumu OHNO
}

\begin{abstract}
Strong-motion characteristics during the 2011 Tohoku earthquake are summarized. The major characteristics are : 1) predominant at short periods and large accelerations are observed in wide area, 2 ) significant spatial variation due to the differences of substructure conditions, and 3 ) very long duration due to wide faulting rupture area.

Key words : 2011 Tohoku earthquake, strong-motion, large acceleration, duration

和文要旨

東北地方太平洋沖地震で観測された強震記録の概要を紹介した。主な特徵としては，1）短周期卓越型で広域に渡る大加速度，2) 地盤による相違，3）非常に長い継続時間があげられる。

キーワード：東北地方太平洋沖地震，強震動，大加速度，継続時間
\end{abstract}

\section{1.はじめに}

2011年東北地方太平洋沖地震（M9.0）は，この地域 で事前に想定されていた規模をはるかに上回る地震であ り，沿岸域の津波被害のみならず広域に渡る地盤震動で 多くの構造物被害や地盤災害を引き起こした。今回の地 震は，比較的高密度な強震観測網で観測された初めての 巨大地震でもある。本稿では，東北地方太平洋沖地震で 観測された強震記録の主な特徵について述べる。

\section{2. 地震の概要}

東北地方太平洋沖地震の主な諸元 ${ }^{1)}$ と被害概要" を表一 1 に示す。Mw9.0は日本観測史上最大級であり，東北 地方太平洋沿岸の広い範囲で震度 6 弱以上を観測した。

この地震の発生以前, 地震調査研究推進本部では, 過 去の地震の発生状況から日本全国の地震の長期評価を行 い，東北地方太平洋沿岸では図 -1 のように複数のセグ メントに分けていだ”。このうち宮城県沖の領域ではM 7 クラスの地震が繰り返し発生し，2005年にもM7.2の 地震が起こったものの, 地震発生のポテンシャルは残っ ていると思われていた。また，三陸沖南部海溝寄りの領 域は宮城県沖の領域と連動して破壊することが考慮され ていた。一方，この地域で過去に大津波を起こした地震 の発生が指摘されていたが，それを反映させた長期評価 は審議中であり ${ }^{4)}$, 地震発生時点で図－1のセグメント を超えた破壊は想定地震に反映されていなかった。

東北地方太平洋沖地震の押㧍よその破壊領域を図 - 1 に重ね書きした。地震発生前の長期評価の想定をはるか に超え，宮城県沖の領域を含む複数のセグメントにまた がる長さ約 $500 \mathrm{~km} ，$ 幅約 $200 \mathrm{~km}$ の領域が破壊した。ただ

* 連絡著者/corresponding author

a) 東北大学・災害科学国際研究所

International Research Institute of Disaster Science, Tohoku University

厂 980-8579 宮城県仙台市青葉区荒卷字青葉6-6-11-1103

Aoba-yama, 6-6-11-1103, Aoba-ku, Sendai 980-8579, Japan
し後述のとおり，全ての領域が一様に滑った訳ではなく， 津波・地殸変動と強震動を引き起こした場所が空間的に 全く異なる複雑な破壊であった。

\section{3. 東北地方太平洋沖地震で観測された強震動}

主な強震観測網では，防災科学技術研究所のK-NET, KiK-net ${ }^{5)}$ ，気象庁および自治体 ${ }^{6}$ ，港湾空港技術研究所 ${ }^{7}$,

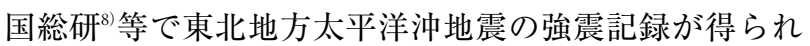
ている。な扔, 仙台市では東北大学 $\left.{ }^{9}\right)$ と東北工業大学 ${ }^{10}$ による観測でも記録が得られている。

上記のデー夕を用いて, 計測震度 $(\mathrm{JMAI}) \cdot$ 水平最大 加速度 $(\mathrm{PGAH}) \cdot$ 水平最大速度 $(\mathrm{PGVH})$ を求め, さらに 等価周期 (Teq) を次式で算定した。

$\mathrm{Teq}=2 \pi(\mathrm{PGVH} / \mathrm{PGAH})$

その際, 最大速度はカットオフ周期10sのローカット フィルタをかけた加速度積分波形の最大值で求めている。 上記の機関で観測された主な記録の諸元を表 - 2 に示

表一 1 地震諸元 ${ }^{1)}$ と被害概要 ${ }^{2)}$

Table 1 Summaries of the 2011 Tohoku earthquake

\begin{tabular}{|c|c|}
\hline 発生時刻 & 平成23年3月 11 日 14時46分 18.1 秒 \\
\hline 震源位置 & $\begin{array}{l}\text { 三陸沖（北緯38度06.2分, } \\
\text { 東経142度51.6分, 深さ24km） }\end{array}$ \\
\hline 規模 & モーメントマグニチュードMw=9.0 \\
\hline 震度 7 & 宮城県(栗原市) \\
\hline 震度 6 強 & 宮城・福島・茨城・栃木県 \\
\hline 震度 6 弱 & $\begin{array}{l}\text { 岩手・宮城・福島・茨城・栃木・群馬・ } \\
\text { 埼玉 ·千葉県 }\end{array}$ \\
\hline 津波高さ & $\begin{array}{l}\text { 相馬 } 9.3 \mathrm{~m} \text { 以上，等 } \\
\text { (検潮所データ欠損前最大值) }\end{array}$ \\
\hline 人的被害 & $\begin{array}{l}\text { 死者 } 18,131 \text { 人，行方不明者 } 2,829 \text { 人， } \\
\text { 負傷者 } 6,194 \text { 人 }\end{array}$ \\
\hline 住家被害 & $\begin{array}{l}\text { 全壊129,391棟, 半壊265,096棟, 一部 } \\
\text { 破損743,298棟 }\end{array}$ \\
\hline
\end{tabular}


す。ここで，自治体の観測点で波形が残されていない地 点については加速度最大值（3 成分のうちの最大值）の みを, 計測震度算定用の 3 成分合成加速度最大值PGA 3 しか残されていないものについては, 東北地方太平洋 沖地震の記録から求めた換算式 11

$$
\mathrm{PGAH}=0.9141 \cdot \mathrm{PGA} 3
$$

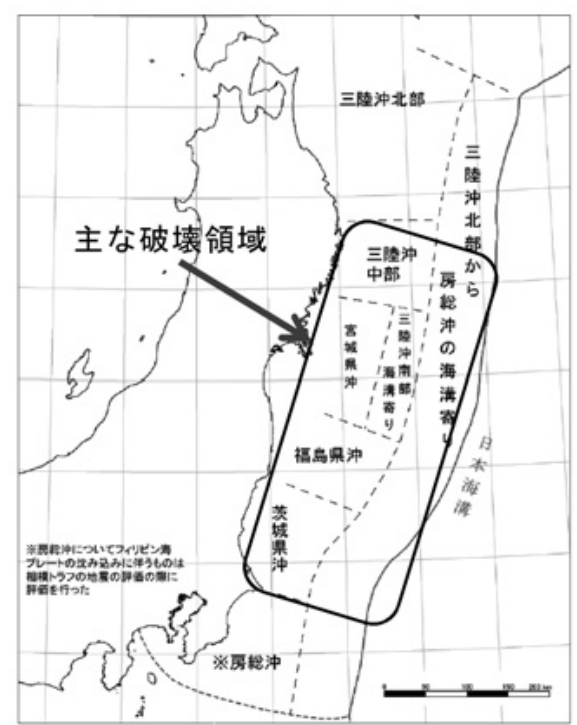

図ー 1 長期評価のセグメンドに主な破壊領域を加筆

Fig. 1 Fault-segment map of long-term evaluation with major rupture area of the 2011 Tohoku earthquake
による水平最大加速度の換算值PGAHを示した。

この表から, MYG004（宮城県栗原市築館）, TCGH 16 (栃木県芳賀町) , CCHG（仙台市若林区荒井）の 3 ケ 所で震度 7 が観測されていること, 最大加速度では, 上 記MYG004と宮城県川崎町で2.7Gが観測されているの に加え，宮城県・福島県・茨城県・杤木県で $1 \mathrm{G}$ 超え る值が観測されていることがわかる。

ただし，MYG004については崖上に位置することによ る増幅の影響 ${ }^{12}$ に加え，地震計の浮き上がりの可能性が 指摘されており ${ }^{13)}$ ，観測值をそのままその場所の地動を 表すものとして扱ってよいか検討が必要な地点もある。

\section{1 強震動指標の分布}

図- 2 に計測震度值の分布を示す。K-NETの主な地 点のNS方向の加速度波形も図中に示すと同時に，表層 地質区分図 ${ }^{14)}$ も併せて示している。また，図－3に水平 最大加速度 ·水平最大速度と等価周期の分布を示す。こ れらの図表から下記の傾向が読み取れる。

・加速度波形は福島県北部以北では大きく 2 つの波群で 構成されているが，それより南部では 1 つ波群に なっている。なお，それぞれに対応した複数の強震動 生成域が推定されている ${ }^{15)}$ 。

・最大速度は概ね $100 \mathrm{~cm} / \mathrm{s}$ 内に収まっている。 $50 \mathrm{~cm} / \mathrm{s}$ 以上は主に宮城県中央部と関東平野の一部（表層地質 区分図との対応ではいずれも第 4 紀層分布域）で観測 されており，表層地盤による増幅の影響が表れている

表－ 2 2011年東北地方太平洋沖地震の主な記録（計測震度順）

Table 2 List of ground motion records during the 2011 Tohoku earthquake (order of JMA intensity)

\begin{tabular}{|c|c|c|c|c|c|c|c|}
\hline No & 機関 & 银测点 & 場所 & $\begin{array}{l}\text { 部润 } \\
\text { 震度 } \\
\end{array}$ & $\begin{array}{r}\text { 最大加速度 } \\
(\mathrm{cm} / \mathrm{s} / \mathrm{s})\end{array}$ & $\begin{array}{l}\text { 最大速度 } \\
(\mathrm{cm} / \mathrm{s})^{* 2}\end{array}$ & $\begin{array}{r}\text { 等亚周期 } \\
\text { (s) }\end{array}$ \\
\hline 1 & 防災科研 & MYG004 & 宮城県栗原市箂館 & 6.6 & 2700 & 109 & 0.25 \\
\hline 2 & 防災科研 & TCGH16 & 枋木県芳䝷町 & 6.5 & 1197 & 71 & 0.37 \\
\hline 3 & 東北工亲大学 & smt.CCHG & 仙台市若林区荒井 & 6.5 & 1074 & 115 & 0.60 \\
\hline 4 & 防災科研 & IBR003 & 茨城県日立市助川町 & 6.4 & 1598 & 69 & 0.27 \\
\hline 5 & 防災科研 & IBR013 & 茨城県錊田市当間 & 6.4 & 1355 & 68 & 0.32 \\
\hline 6 & 東北工業大学 & smt.IWAK & 仙台市宮城野区岩切 & 6.4 & 859 & 74 & 0.76 \\
\hline 7 & 東北大学 & dcr.009 & 仙台市泉区松森 & 6.4 & 821 & 83 & 0.64 \\
\hline 8 & 防災科研 & MYG013 & 仙台市宮城野区苦竹 & 6.3 & 1517 & 74 & 0.31 \\
\hline 9 & 防災科研 & TCG014 & 妳木穆茂木町 & 6.3 & 1205 & 60 & 0.32 \\
\hline 10 & 宮城県 & 石巻市挑生町 & 宮城県石巻市桃生町 & 6.3 & 901 & & \\
\hline 11 & 福岛県 & 大繁町下野上*1 & 福岛県大熋町下野上 & 6.3 & 843 & & \\
\hline 12 & 福島県 & 国見町藤田・1 & 福島県国見町藤田 & 6.3 & 568 & & \\
\hline 13 & 宫城県 & 宮城川崎町前川 & 宮城目川婍町前川 & 6.2 & 2692 & 62 & 0.05 \\
\hline 14 & 福島県 & 天栄村下松本 & 福島県天栄村下松本 & 6.2 & 908 & 77 & 0.39 \\
\hline 15 & 宮城県 & 大崎市田尻 & 宮城県大崎市田尻 & 6.2 & 854 & & \\
\hline 16 & 防災科研 & IBRHII & 茨城県岩巍町 & 6.2 & 827 & 58 & 0.44 \\
\hline 17 & 茨城県 & 那珂市瓜連 & 茨城県那珂市瓜連 & 6.2 & 723 & 80 & 0.70 \\
\hline 18 & 国緮研 & 8274102 & 気仙沼国道維持出張所 & 6.2 & 570 & 65 & 0.71 \\
\hline 19 & 気象庁 & $4 \mathrm{B9}$ & 大绮市古川三日町 & 6.2 & 550 & 80 & 0.91 \\
\hline 20 & 宮城県 & 登米市米山町 & 宮城県登米市米山町 & 6.2 & 487 & 76 & 1.54 \\
\hline 21 & 東北工菜大学 & smt.NAKI & 仙台市泉区七北田 & 6.1 & 1853 & 73 & 0.09 \\
\hline 22 & 防災科研 & FKS016 & 福島県白河市新白河 & 6.1 & 1295 & 55 & 0.27 \\
\hline 23 & 防災科研 & TCG009 & 杪木県日光市今市 & 6.1 & 1186 & 46 & 0.25 \\
\hline 24 & 防災科研 & IBR005 & 茨城県笠間市石井 & 6.1 & 967 & 56 & 0.36 \\
\hline 25 & 质木県 & 高根沢町石末 & 桥木㲏高根沢町石末 & 6.1 & 874 & 66 & 0.39 \\
\hline 26 & 防災科研 & TCGH13 & 板木県馬頭町 & 6.1 & 840 & 62 & 0.47 \\
\hline 27 & 宮城県 & 栗原市高清水 & 宮城県栗原市高清水 & 6.1 & 821 & & \\
\hline 28 & 栃木県 & 大田原市湯津上 & 㭘木県大田原市渴津上 & 6.1 & 691 & 65 & 0.62 \\
\hline 29 & 福岛県 & 新地町谷地小屋 & 福岛県新地町谷地小屋 & 6.1 & 696 & 82 & 0.62 \\
\hline 30 & 宮城県 & 名取市増田 & 宮城県名取市増田 & 6.1 & 655 & 105 & 0.69 \\
\hline
\end{tabular}

•1 3成分合成加速度最大值PGA3から最大加速度PGAHにPGAH = 0.9141·PGA3で換算

*2 カットオフ周期10sで計算 

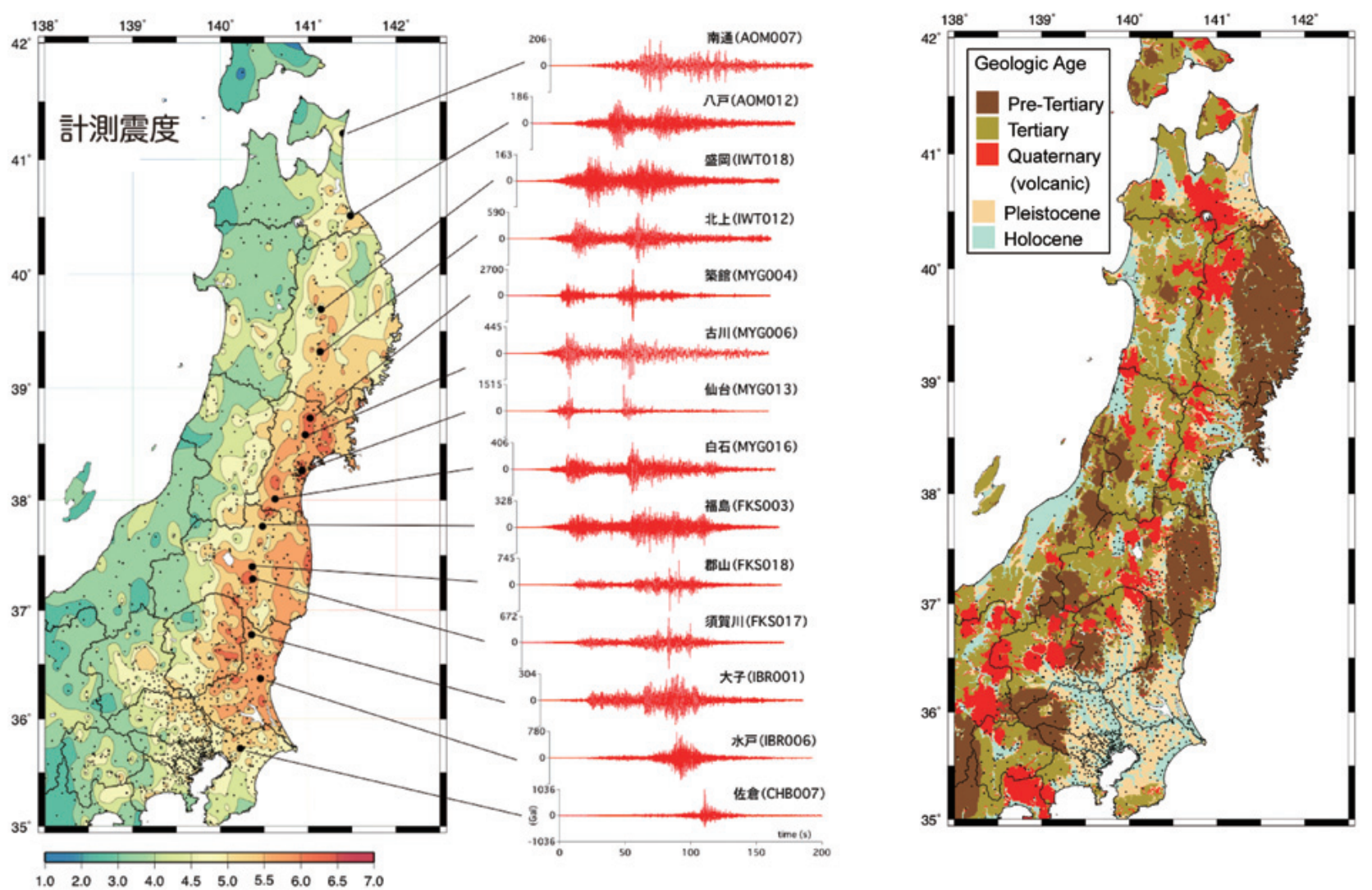

図－２２011年東北地方太平洋沖地震の計測震度分布・加速度波形（左）と表層地質図 ${ }^{(4)}($ 右）

Fig. 2 JMA intensity map with acceleration waveforms of the 2011 Tohoku earthquake (Left) ; geologic map (Right)

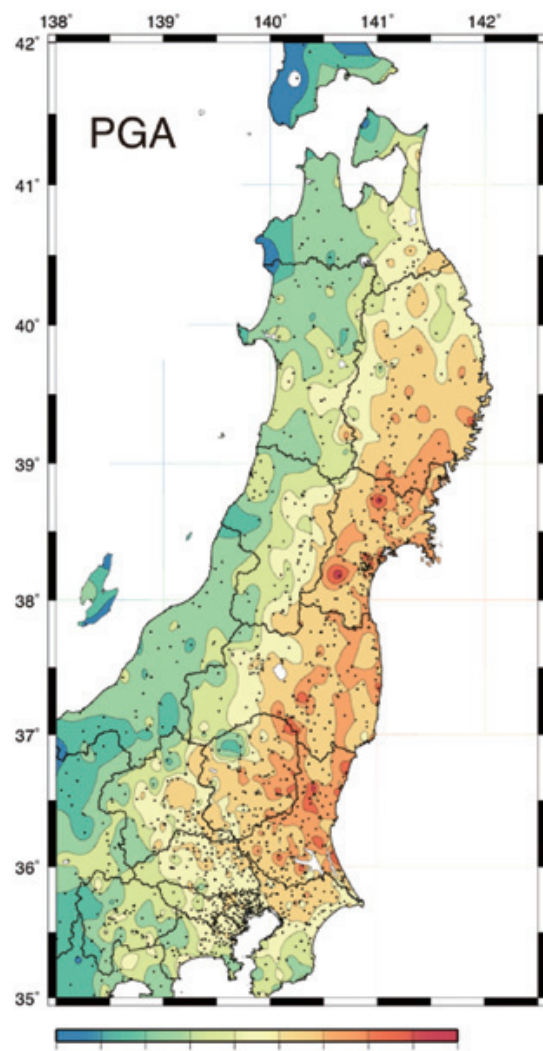

$51020 \quad 5010020050010002000$ (Gal)

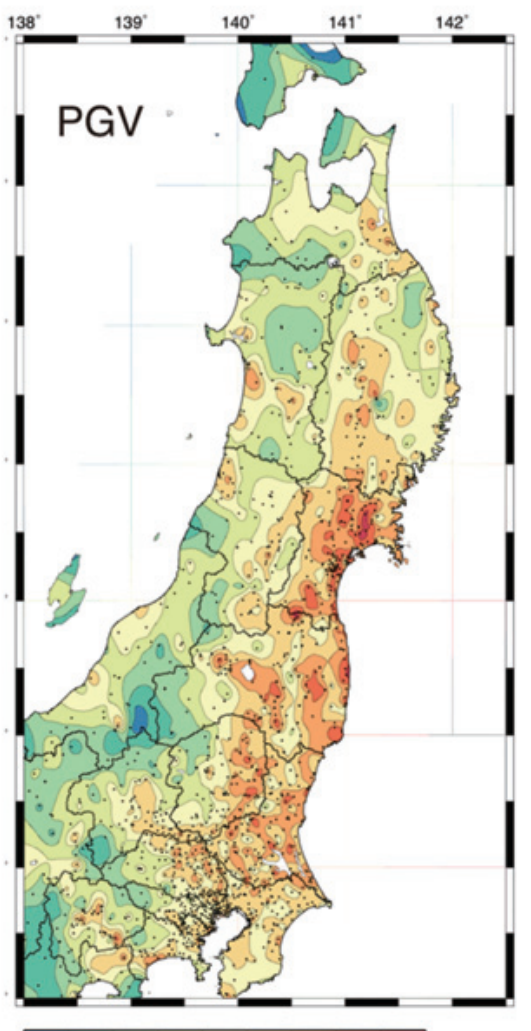

$\begin{array}{llllllllll}1 & 1.8 & 3.2 & 5.6 & 10 & 18 & 32 & 56 & 100 & (\mathrm{~cm} / \mathrm{s})\end{array}$

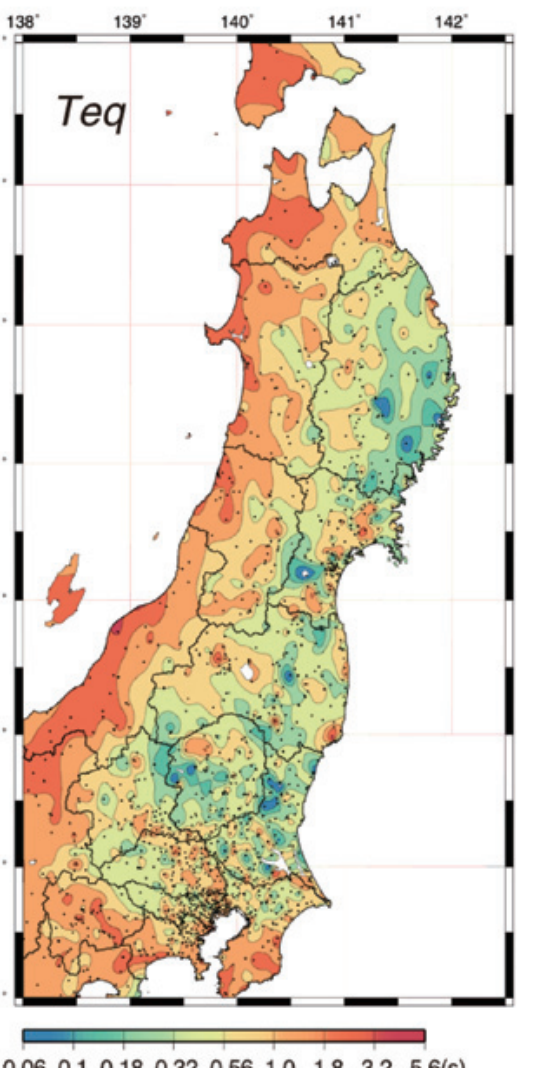

$\begin{array}{lllllllll}0.06 & 0.1 & 0.18 & 0.32 & 0.56 & 1.0 & 1.8 & 3.2 & 5.6(\mathrm{~s})\end{array}$

図一３2011年東北地方太平洋沖地震の最大加速度分布（左）・最大速度分布（中）・等価周期分布（右）

Fig. 3 Maps of PGA(left), PGV (center), equivalent period (right) of the 2011 Tohoku earthquake 
ものと思われる。

•太平洋岸では等価周期で 0.5 秒以下の值が広く分布し ており, 多くの地点で短周期が卓越していたと推定さ れる。ただし宮城県中央部の平野や東京湾沿岸部など の沖積平野では周期 1 秒ないしそれ以上になっており, 地盤による相違も大きい。

\section{2 主な加速度記録とその特性}

図 -4 は東北地方太平洋沖地震と過去の内陸地震被災 域で観測された記録のPGAとPGVの関係である。2011/ $4 / 7$ の宮城県沖の地震（M7.1）及び川瀬 ${ }^{16)}$ による大被 害生成レベル $\left(P G A \geqq 800 \mathrm{~cm} / \mathrm{s}^{2}, P G V \geqq 100 \mathrm{~cm} / \mathrm{s}\right)$ も記 入している。この図から, 東北地方太平洋沖地震では最 大加速度は大きいが，最大速度は過去の被災域の記録に 達しないことがわかる。

図 -5 は, 東北地方太平洋沖地震の記録と, 過去の地 震の甚大な被害域で観測された記録（例として, 1995年 兵庫県南部地震の鷹取及び2004年新潟県中越地震の川口 町）について，擬似速度応答スペクトルを比較したもの である。（a）では計測震度が大きな 3 地点について示し ているが，鷹取及び川口町では低層建物の被害に影響が 大きい周期 $1-2$ 秒 ${ }^{17)}$ が卓越しているのに対して，東北 地方太平洋沖地震の記録は短周期は大きいものの周期 1 秒付近の周期帯の振幅は小さい。

一方 (b) は宮城県大崎平野の中心部, 古川地区に位置 するK-NET MYG006,気象庁 4 B9, 国総研8274202（大 崎出張所）を比較したものである。周期 1 秒前後で鷹取 · 川口町に近づており，こういった軟弱地盤の場所では 過去の被災域で観測されたレベルに近い記録も観測され ており，地盤による差異が非常に大きいことがわかる。
なお, 2.7Gを観測したMYG004（築館）周辺ではほと んど被害がないが，古川では1995年兵庫県南部地震及び 2004年新潟県中越地震の震源域での低層建物の被害率に は達しないものの，建物被害も報告されている ${ }^{18)}$ 。

\section{4. 経験式との対応}

東北地方太平洋沖地震の最大加速度，最大速度を司 · 翠川 ${ }^{19)}$ の経験式と比較した結果を図 -6 および図 -7 に 示す。断層面がおおよそ $500 \mathrm{~km} \times 200 \mathrm{~km} に も$ 達すること から，経験式を適用する場合は距離の定義により結果が 大きく異なる。断層面からの距離の取り方は図 -8 に示 すように複数あるが ${ }^{20)}$ ，ここでは断層面からの最短距離 Rrup 等価震源距離Xeq（断層面を観測点が受けるエ ネルギーが等価な点震源に置換したときの距離）両方の 結果を示し，比較のため2003年十勝沖地震（M8.2）の 観測值を重ね書きしている。

経験式を適用する際には，マグニチュードはMw9.0 （十勝沖地震はMw8.2）とし，地盤は平均的なもの（補 正なし）とした。東北地方太平洋沖地震に対しては，鈴 木ほか ${ }^{21}$ の断層面（図一 6 右図）により最短距離を計算 し，川辺ほか ${ }^{15)}$ の強震動生成域（図 -7 右図）から放出 される短周期レベルで重みづけして等価震源距離を求め た。なお，他の震源モデルを用いても結果に大きな相違 はない。十勝沖地震に対しては，Hondaほか ${ }^{22)}$ の震源モ デルから最短距離および等価震源距離を計算している

この図から以下のことがわかる。

1 ) 断層最短距離の場合，同じ距離で東北地方太平洋沖 地震と 2003 年十勝沖地震の観測値はほほ等しくなり, 経験式でM9.0として評価した場合は過大評価となる。

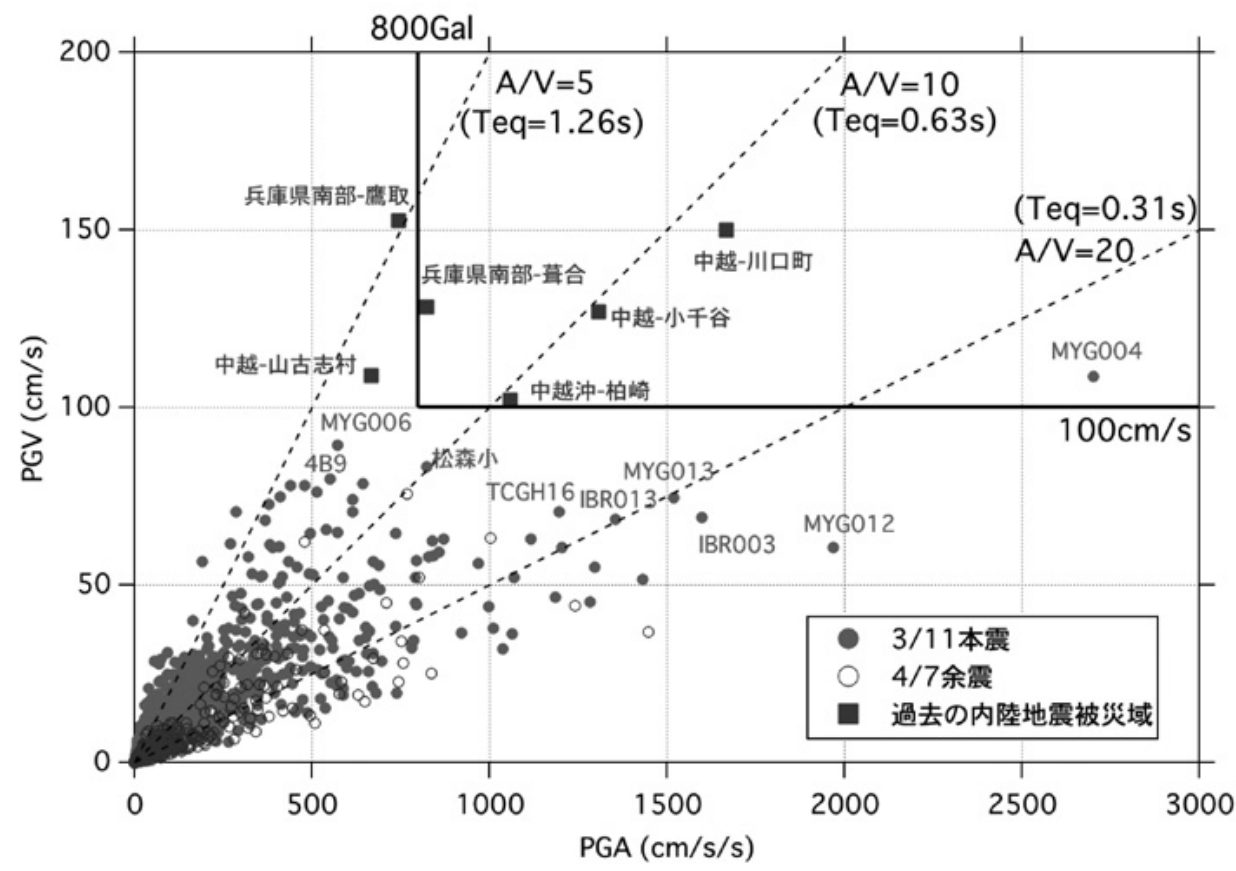

図一４東北地方太平洋沖地震と過去の内陸地震被災域のPGA-PGV関係

Fig. 4 PGA-PGV relationships for the records of the 2011 Tohoku earthquake, $4 / 7$ aftershock, and for the records observed in the disastrous area of the past inland earthquakes. 

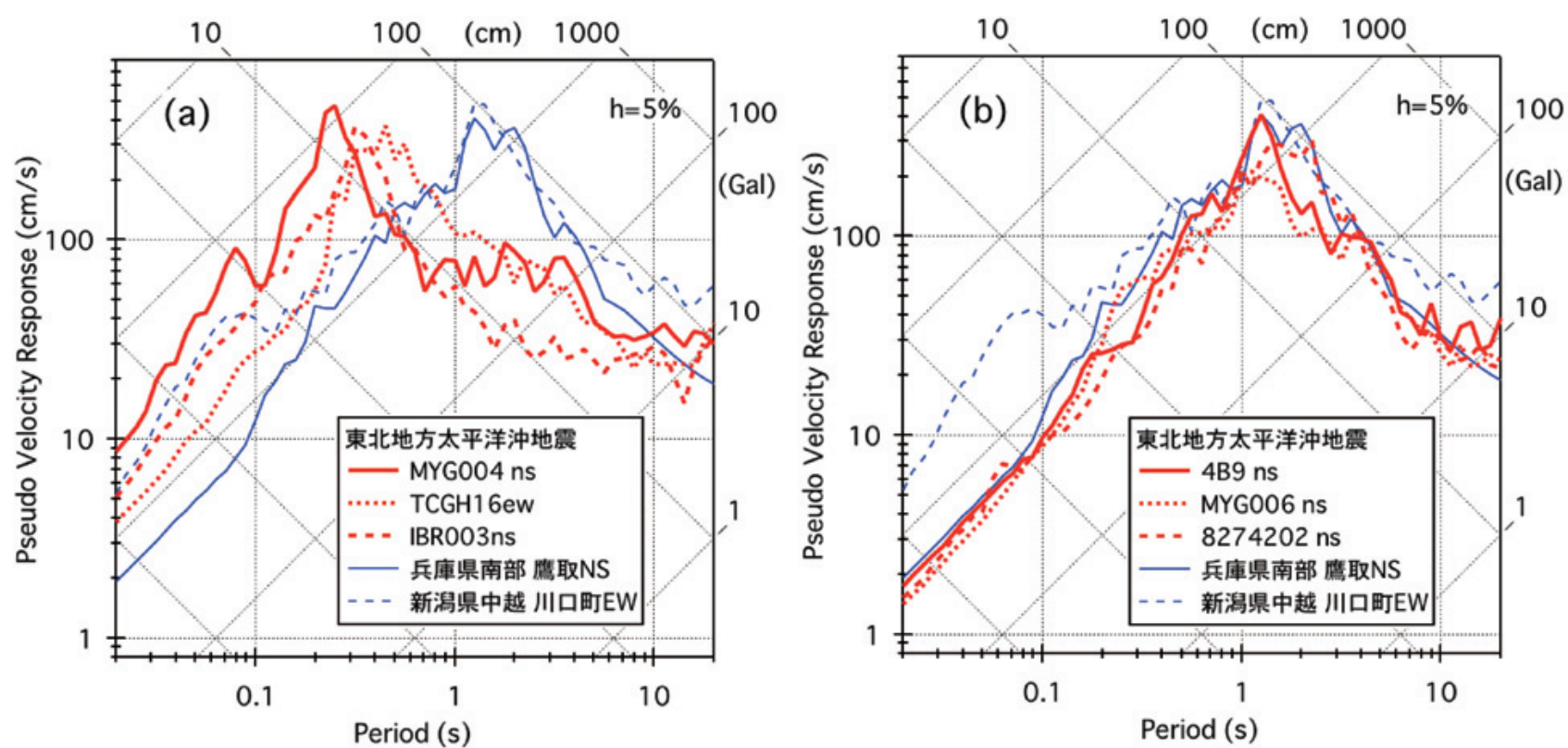

図－5＼cjkstart東北地方太平洋沖地震と過去の内陸地震被災域擬似速度応答スペクトル

(a) 計測震度が大きい地点（b）古川市街地

Fig. 5 Pseudo-velocity response spectra for the records observed during the 2011 Tohoku earthquake and observed in the disastrous area of the past inland earthquakes.

(a) Sites with large JMA intensity, (b) Furukawa area of Ohsaki city, Miyagi prefecture.
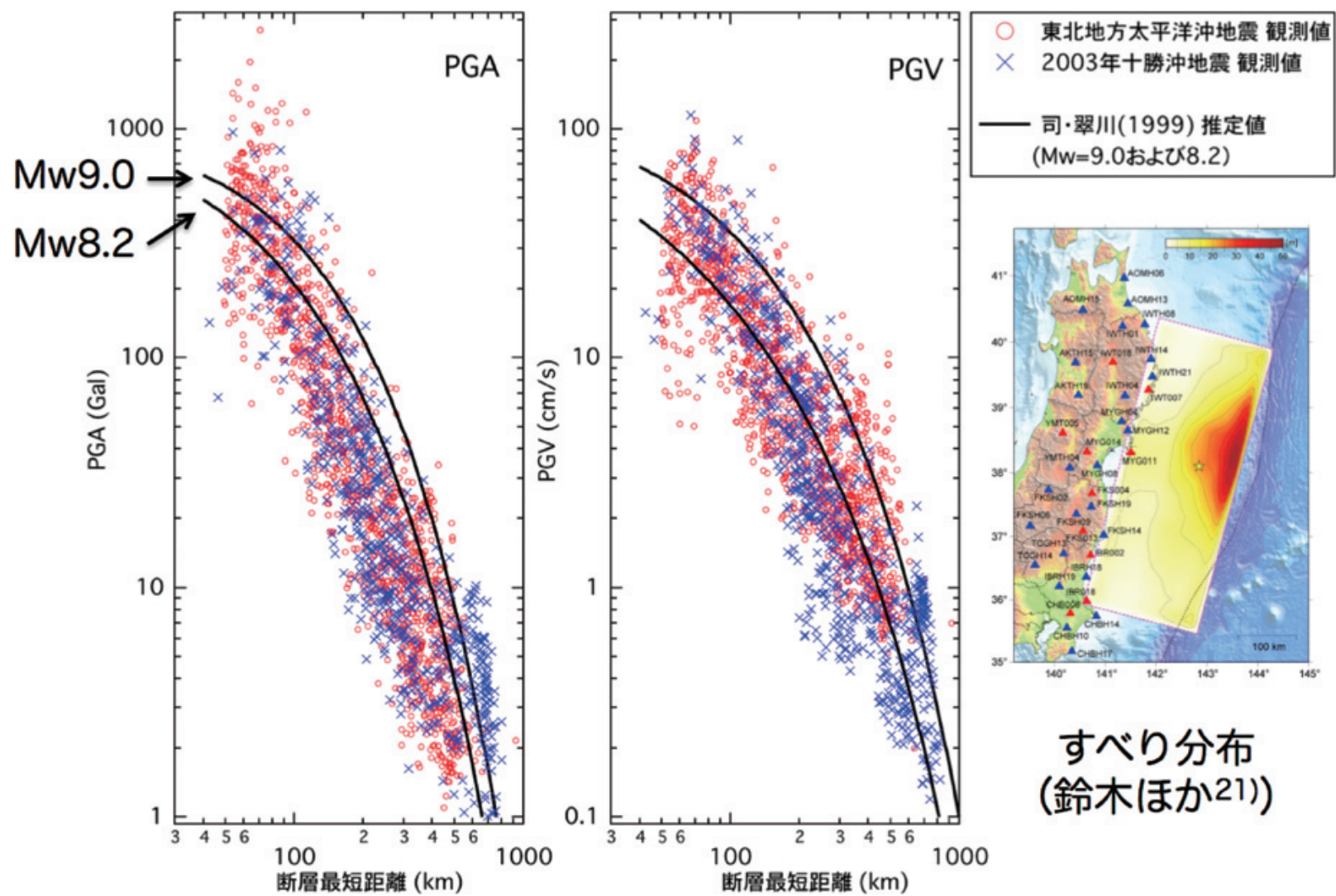

図一 6 東北地方太平洋沖地震PGA, PGVと経験式との比較（断層最短距離）

Fig. 6 Observed and predicted PGA, PGV for the 2011 Tohoku earthquake records (fault distance)

2 ）一方等価震源距離の場合は，東北地方太平洋沖地震 の観測值は十勝沖地震よりも系統的に大きく，経験 式でM9.0として評価した場合は，観測值のばらつ
きは大きいものの，概ね観測值と整合する。

これは，図ー8に示すように強震動を生成した領域は 断層面全体のごく一部であるにもかかわらず，最短距離 

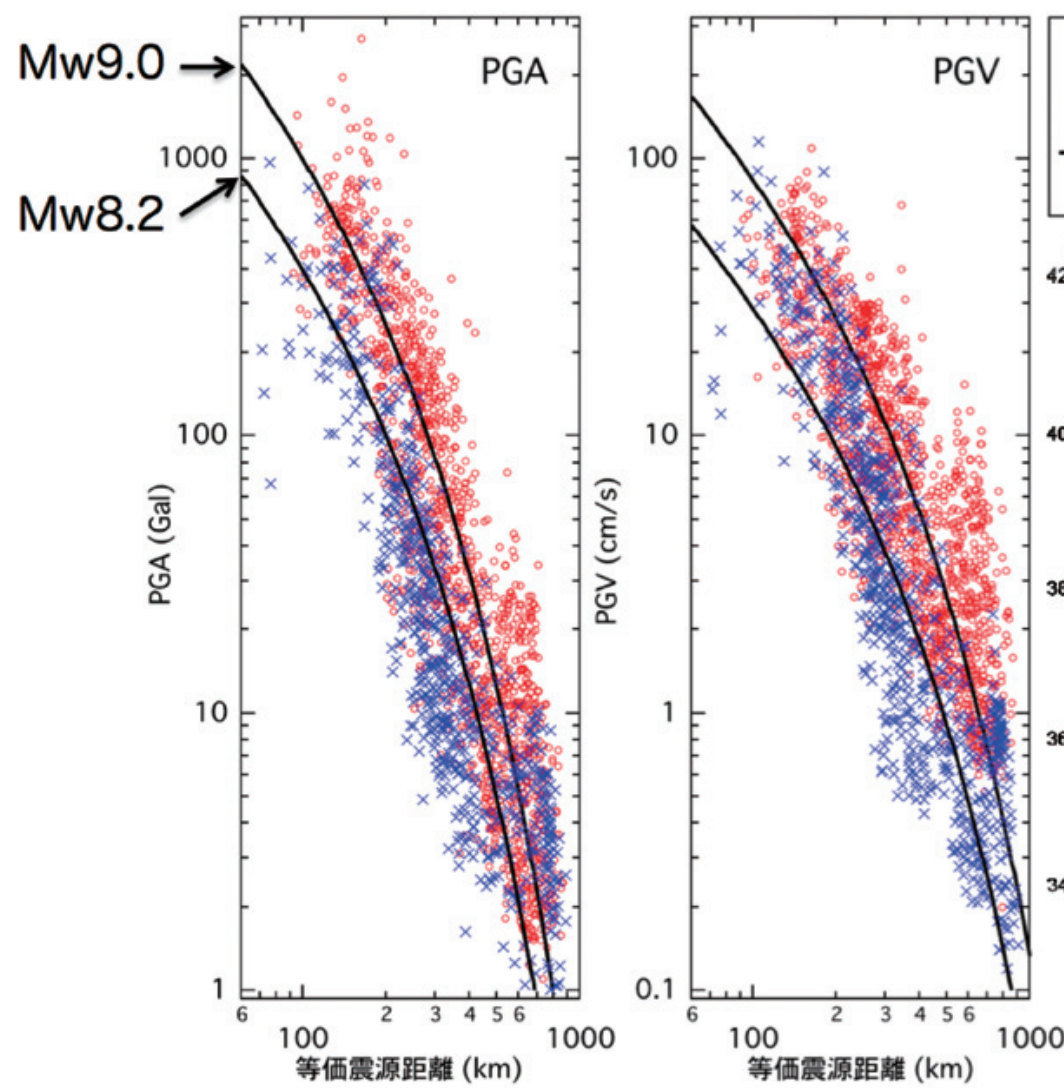

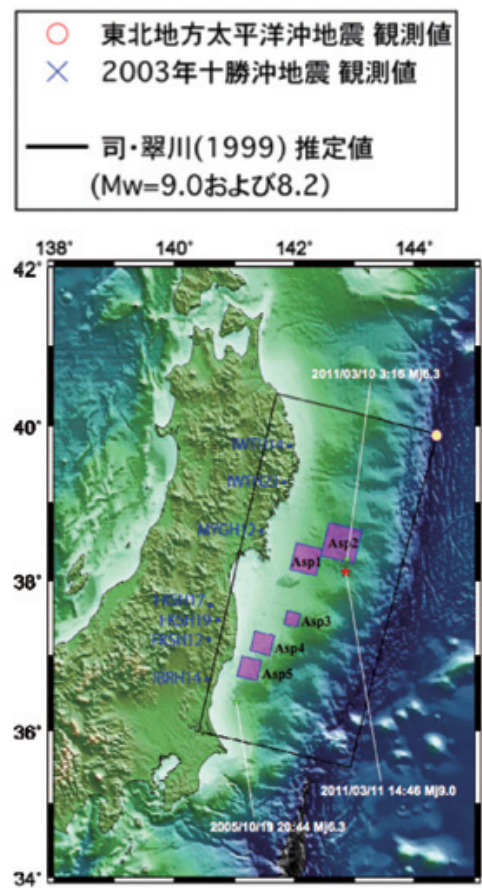

強震動生成域

(川辺ほか 15))

図- 7 東北地方太平洋沖地震PGA, PGVと経験式との比較（等価震源距離）

Fig. 7 Observed and predicted PGA, PGV for the 2011 Tohoku earthquake records (equivalent hypocentral distance)

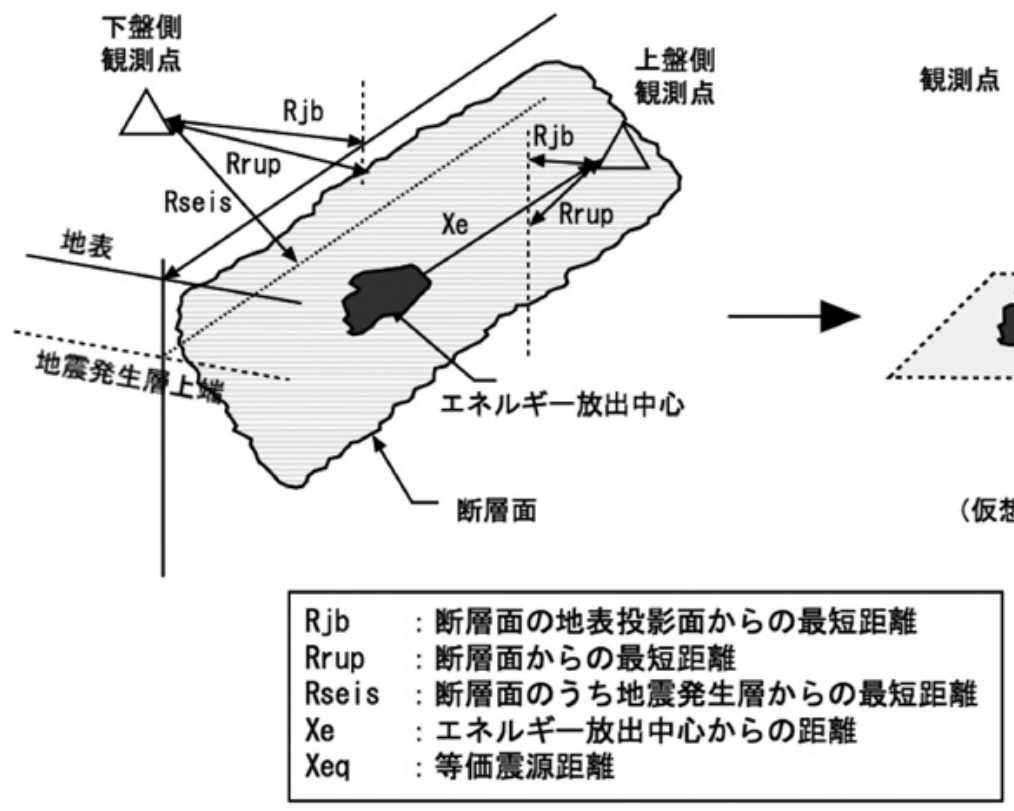

図-8 断層面からの距離の定義

Fig. 8 Variation of source-to-site distances

では断層面のうち観測点に最も近い位置を強震動に寄与 する位置として選んでいるためと思われる。等価震源距 離の場合は強震動生成域で重みづけして距離を求めてお り，算定に手間はかかるものの上記のような問題は原理 的に生じない。
西村ほか ${ }^{23)} も$ 同様の結果を得ており，東北地方太平洋 沖地震の強震動強さは, 距離に注意すれば, 既存の経験 式と整合することがわかる。ただし，このような巨大地 震は始めて観測されたので, 経験式においてマグニ チュード，距離とも外抻になっている（司・翠川のデー 

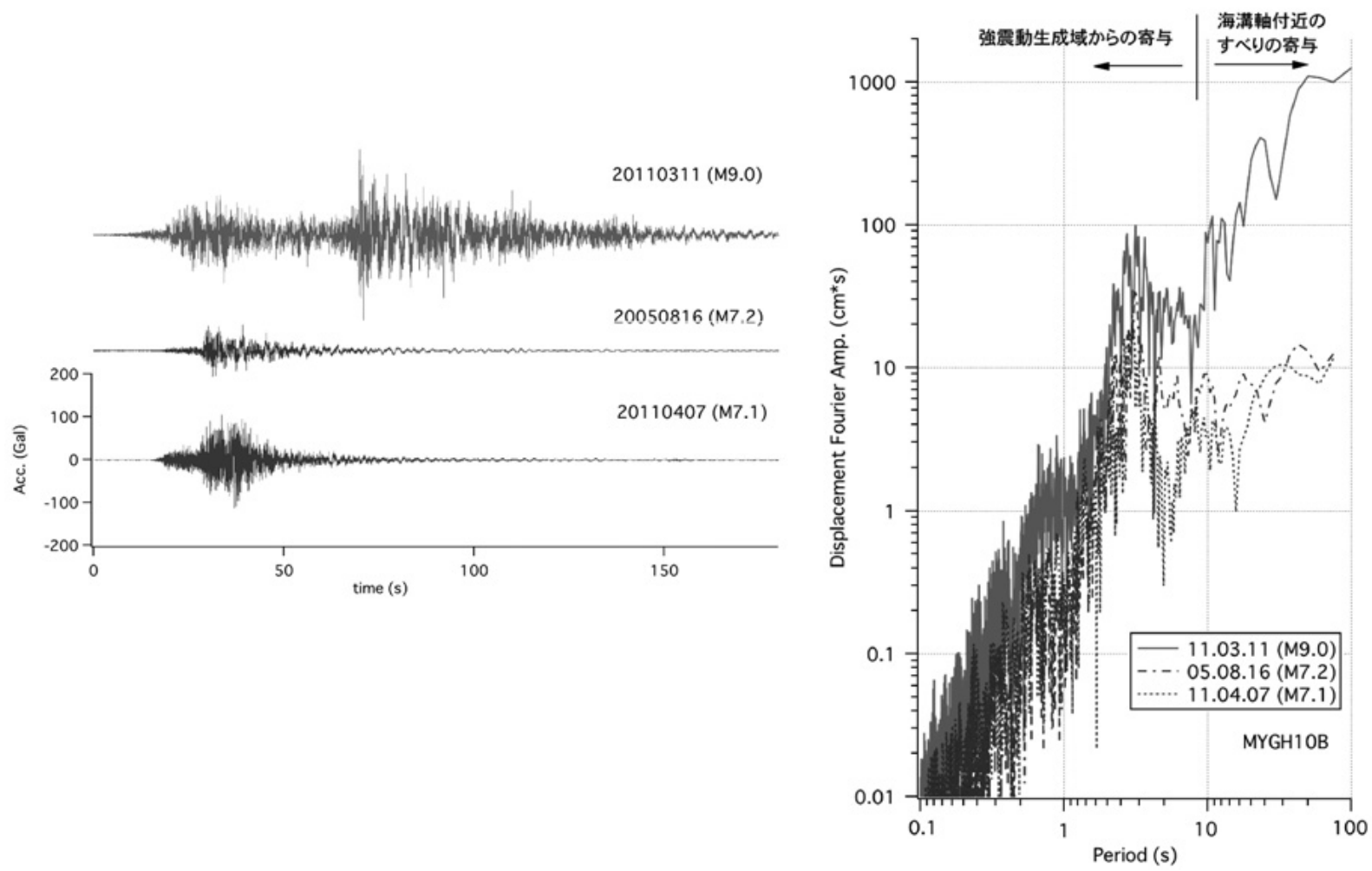

図－9 東北地方太平洋沖地震（M9.0） とM 7 クラスの地震動波形と周期特性

Fig. 9 Comparison of acceleration waveforms and their spectra between the 2011 Tohoku earthquake (M9.0) and M 7 -class earthquakes

夕範囲は $\mathrm{M} \leqq 8.3$, 距離 <概ね $300 \mathrm{~km} ）$ ことから，今後よ り詳細な検討が必要と思われる。

\section{M 7 クラスの強震動との比較}

上記の通り，短周期卓越で加速度が大きめという傾向 はあるが，それを除けば強震動振幅としては特に大き かった訳ではない。ではM 9 クラスとしての地震動の特 徴はどこに表れているのであろうか。

図 - 9 は宮城県山本町のKiK-net地中観測点（MYGH 10）で,2005年, 2011年の宮城県沖の地震（M7.2, M7.1） と東北地方太平洋沖地震の加速度波形と変位フーリエス ペクトルを比較したものである。破壊領域自体は数 100 $\mathrm{km}$ に及んだため, 東北地方太平洋沖地震の震動継続時 間はM 7 クラスに比べて非常に長くなっているが，加速 度最大值はそれほど大きくなっている訳ではない。

次にM 7 クラスとスペクトルを比較する。一般に地震 規模が大きくなるとより長周期が卓越するが, 今回の地 震の場合は周期带域別に地震動の生成域も異なる。ごく 長周期（10s以上）では海溝沿いの浅部の寄与が大きく (図-6 右図 $)^{21)}$ ，50mにも達するすべり量が周期10s以 上のオーダー違いの振幅を生み出している。一方周期 10 $\mathrm{s}$ よ短周期（いわゆる強震動の帯域）ではより陸域に 近い部分から強震動が生成されているが $(\text { 図 }-7 \text { 右図 })^{15)}$, こちらはごく長周期ほどの差は生じていない。

今回の地震はこのように周期帯域により 2 つ異なる
側面を持った地震であり，M9 クラスとしての地震動の 特徵は, 主に通常の強震動の周期帯から外れた周期 $10 \mathrm{~s}$ 以上での卓越と, 非常に長い継続時間として現れている。

\section{5. まとめ}

東北地方太平洋沖地震で観測された強震記録の概要を 紹介した。主な特徵としては, 1）短周期卓越型で広域に 渡る大加速度, 2) 地盤による相違, 3) 非常に長い継続時 間があげられる。このうち 2） 3）については他のM 9 クラスの地震でも共通するものと思われるが, 宮城県沖 で起きる地震の強震動は短周期が卓越することは以前か ら知られており例えは24)，1）についてはこの地域の特徴で ある可能性もある。今後より詳しく成因を検討していく 必要があると思われる。

\section{謝辞}

防災科学技術研究所, 気象庁, 自治体, 港湾空港技術 研究所, 国土技術政策総合研究所, 東北工業大学の記録 を使用し，作図にはGMT ${ }^{25}$ を利用しました。

\section{引用文献}

1 ）気象庁（2011）：災害時地震 - 津波速報平成23年（2011年）東 北地方太平洋沖地震.

2 ) 消防庁 (2012) : 平成23年 (2011年) 東北地方太平洋沖地震 (東 日本大震災) について (第146報)。

3 ) 地震調查研究推進本部（2009）：三陸沖から房総沖にかけての 
地震活動の長期評価の一部改訂について

4 ）地震調査研究推進本部（2012）：今後の地震動ハザード評価に 関する検討〜2011年・2012年における検討結果〜。

5 ) http://www.kyoshin.bosai.go.jp/kyoshin/

6 ）気象庁（2012）：加速度デー夕（95型震度計波形データ） 2011 年，気象業務支援センター。

7 ) http://www.mlit.go.jp/kowan/kyosin/eq.htm

8 ) http://www.nilim.go.jp/lab/rdg/index.htm

9 ) Susumu Ohno, Masato Motosaka, Akihiro Shibayama, Kazuya Mitsuji (2012) : Strong-motion characteristics in Sendai city during the 2011 Tohoku earthquakes, Japan, Proc. of 15 WCEE, Paper No. 3631.

10）神山眞・松川忠司・穴澤正宏（2011）：2011年東北地方太平洋 沖地震に扔ける東北工業大学アレー強震システムSmall-Titan による強震記録について, 東北工業大学強震観測グルー プ,2011年 4 月16日.

11）大野晋 (2011) : 東北地方太平洋沖地震とその余震における強 震動分布, 日本地震工学会 ·大会 - 2011梗概集, pp. 490-491.

12）山中浩明・津野靖士・地元孝輔・加藤圭・ヤダブダカール · 山田伸之・福元俊一・江藤公信 (2011)：2011年東北地方太平 洋沖地震で震度 7 が観測された地域での余震及び微動観測, 日本地震学会講演予稿集, pp. $2-31$.

13）源栄正人· Tsoggerel Tsamba（2011）：Investigation of High Acceleration Records at K-NET Tsukidate Station During the2011off the Pacific Coast Tohoku Earthquake, 日本地震 工学会大会 -2011 梗概集, pp. 24-25.

14）若松加寿江 - 松岡昌志 (著), 杉浦正美 (著), 久保純子 (著), 長谷川浩一 (著) (2005)：日本の地形・地盤デジタルマップ, 東京大学出版会.

15）川辺秀憲・釜江克宏・上林宏敏（2011）：2011年東北地方太平 洋沖地震の震源モデル，日本地震学会講演予稿集 2011年度
秋季大会，B22-05.

16）川瀬博（2001）：建物の地震被害の予測とその軽減への展望, 地学雑誌, 110, pp. 885-899.

17）境有紀・䋶纈一起・神野達夫（2002）：建物被害率の予測を目 的とした地震動の破壊力指標の提案，日本建築学会構造系論 文集, No. 555, pp. $85-91$.

18）日本建築学会（2011）：2011年東北地方太平洋沖地震災害調査 速報.

19）司宏俊・翠川三郎：断層タイプ及び地盤条件を考虑した最大 加速度・最大速度の距離隇衰式, 日本建築学会構造系論文 集, 523, 63-70, 1999.

20）日本建築学会（編）（2005）：地盤震動一現象と理論.

21）鈴木亘・青井真・関口春子（2011）：近地強震記録を用いた 2011年03月11日東北地方太平洋沖地震の震源インバージョン 解析 (2011/08/12改訂版), http://www.kyoshin.bosai. go.jp /kyoshin/topics/Tohoku Taiheiyo_20110311/inversion/.

22) Honda, R., S. Aoi, N. Morikawa, H. Sekiguchi, T. Kunugi and H. Fujiwara (2004) : Ground motion and rupture process of the 2003 Tokachi-oki earthquake obtained from strong motion data of K-NET and KiK-net, Earth Planets Space, 56, pp. $317-322$.

23）西村利光・堀家正則・宮腰研（2011）：2011年東北地方太平洋 沖地震（Mw9.0）の距離減衰特性と距離指標の関係，日本建 築学会大会学術講演梗概集, 21042 .

24) Ohno, S. (2008) : Development of a statistical strong-motion evaluation method considering regional variation of source and path effects in the Tohoku region, Japan, 14th World Conf. Earthq. Eng., 02-0072.

25) Wessel, P. and W. H. F. Smith (1991) : Free software helps map and display data, EOS Trans. AGU, 72, 441.

（原稿受付2012年10月15日，原稿受理2013年 1 月 4 日） 